\title{
A Qualitative Analysis of Public Private Partnership (PPP) Project Contracts in the Roads Sector. A Contextual Elucidation of Uganda National Roads Authority (UNRA)
}

\author{
Innocent Nuwagaba ${ }^{1} \&$ Thekiso Molokwane ${ }^{2}$ \\ 1 Department of Management, School of Business and Management, Uganda Management Institute, Kampala, \\ Uganda \\ ${ }^{2}$ Department of Political and Administrative Studies, University of Botswana, Gaborone, Botswana \\ Correspondence: Innocent Nuwagaba, Department of Management, School of Business and Management, Uganda \\ Management Institute, Kampala, Uganda.
}

Received: April 13, 2020

doi:10.5430/ijba.v11n5p44
Accepted: August 20, 2020

Online Published: September 6, 2020

URL: https://doi.org/10.5430/ijba.v11n5p44

\begin{abstract}
Public Private Partnership Projects continue to gain momentum across the world. Governments in developing countries now find PPP projects as an alternative to conventional financing and providing public infrastructure. Guided by the principal agency theory, this study examines different types of PPP Project contracts in the roads sector with specific focus on the Uganda National Roads Authority (UNRA). Contracting out of projects in the roads sector has led to increased costs of road construction in Uganda. The main objectives of this study are to examine the relevance of the principal-agency theory to the adoption of PPP project contracts by UNRA and establish the types of PPP Project contracts suitable for adoption by UNRA. Data was collected through literature survey and interviews. Study findings revealed that Principal-Agency theory is relevant to adoption of PPP project contracts and that UNRA intends to use mainly management PPP contract. It is concluded that principal-agent relationship is very crucial if the execution of PPP Project contracts is to be a success and that there is a very high chance that UNRA is planning to also adopt the use of Build, Own and Transfer (BOT) PPP Project contract in the roads sector. The study recommends that UNRA should ensure a cordial relationship with private parties and not rely solely on management PPP contracts. The organisation should explore other PPP project contracts such as Private Finance Initiative, Leasing, Design Build, Build Operate and Transfer, and then Design Build and Finance. The choice of contracts should always be based on affordability and value for money.
\end{abstract}

Keywords: public private partnership, project contract, roads, principal, agency

\section{Introduction}

In the past three decades, Public Private Partnerships (PPP) Projects, have become synonymous with provision of public infrastructure. The public finance land scape continues to shrink amid rising need for publicly provided infrastructure. While in the 1980s, Governments resorted to privatization in their effort to, among others finance development, PPP projects have now surfaced as a viable alternative. The concepts of PPP project and privatization have synonymously been used at times. It is critical to note that under a PPP project contract, the state continues to control the facilities managed by the private partner (Tshombe \& Molokwane, 2016) while, under at its extreme, privatization will entail sale of government facilities to the private sector. With regards to the concept of a 'project', it is a temporary organization that is created for the purpose of delivering one or more business products according to an agreed business case. Organizations set up and invest in projects in order to introduce change into their day to day "business as usual" activities (Buehring, 2019). A contract is an agreement between two parties that creates mutual legal obligations (LegalMatch, 2020).

In this paper, the road sector has been chosen, because it accounts for $57.3 \%$ of total PPP project contract spending all over the world and is by far the largest sector of PPP project contract spending among developed countries such as USA and developing countries such as Uganda (Charles, Hugh \& Joseph, 2013). According to Solomon, Srinath., Chika \& Lei (2014), there are various PPP project contracts used in the roads sector which include: Private Finance Initiative, Leasing, Build Operate Transfer (BOT), Management contract and Design Build Finance (DBF) (Matti, 
2013). Conventionally, in many countries all over the world, governments have been the main vehicle behind financing and constructing road infrastructural projects using public procurement but now days, they are involving private sector to finance such projects using PPP contractual arrangements (Alan, 2010). In North America, to rebuild its depreciating road infrastructure, the governments of Canada and USA initiated PPP project contracts to revamp their crumbling infrastructure especially in the road sector in order to retain their competitive position in the world economy (Price Water Coopers, 2009).

In South America, Brazil, in particular, is increasing its level of investments in road transport, energy, education and health using PPP project contracts. All these are essential activities that steer Brazil's sustainable development if it is to overcome her recent economic crisis, fiscal austerity and the high cost of the public debt (Cesar \& Carlos, 2012). In Europe, there are many similarities as far as drivers of execution of PPP projects contracts are concerned. In Austria, Germany and the United Kingdom (UK), governments came up with a wide range of reforms to use PPP contracts in implementing various projects in the roads sector (Andrew, 2013). In the Asia-Pacific region, the countries that have made most progress in the execution of their PPP project contracts are the Philippines, Papua New Guinea, Thailand, the Philippines, Mongolia, Viet Nam, Bangladesh and Indonesia (Asian Development Bank, 2015). In Africa, South Africa has been implementing over 50 PPP project contracts in the road infrastructure development at national and provincial level, and 300 projects at municipal level since 1994 (Hans, 2016). In West Africa, Nigeria and Ghana have earmarked power and road transport as the major sectors that can use PPP project contracts for infrastructural development in order to stimulate its economic growth and development (African Development Fund, 2010).

In East Africa, countries such as Kenya, Tanzania, Burundi, Rwanda and Uganda are initiating PPP project contracts to develop infrastructure such as the standard gauge railway (Mulyungi, 2019). The Ugandan Government views the use of such PPP project contractual arrangements as an important tool in its plan to bridge the infrastructure financing gap in the next five years (Matti, 2013). Although Uganda is currently using contracting out PPP project contracts to construct and rehabilitate a number of roads in different parts of the country such as Mukono Katosi road, it is planning to adopt the use of other PPP project contracts such as management contract for the Kampala-Entebbe expressway and the Build-Operate-Transfer (BOT) PPP Project contract for Kampala-Jinja high way to implement more road sector projects (Tony, 2013). For effective use of such PPP project contracts in the roads sector in Uganda, there is need to understand the nature of the relationship that exists between government and private organisations to work together to deliver services to the citizens through use of principal-agency theory (Holland, 1984). This theory is based on the fact that the success of such PPP projects in the roads sector in Uganda depends on the nature of the relationship between public partners (principal) and private partners (agent) (Bjurstrom, 2020). From these contextual assumptions of PPP projects and how they can be influenced by the relationships between partners, it is possible to understand how the principal-agency theory applies to this study on the use of PPP project contacts in the road sector in Uganda (McQuaid, 2000).

\subsection{The Problem}

While there are a number of studies on various PPP project contracts being used by different countries (Jamali, 2004), exploratory studies focusing on the use and impact of PPP project contracts in the roads sector in Uganda are limited. Moreover, no research has been done to specifically investigate whether the use of different PPP Project contracts can help a country like Uganda to improve its roads sector. A report by New Vision (2016) illustrates that, since 2006, through use of contracting out PPP project contract, 4 trillion Uganda Shillings have been misappropriated by some UNRA staff through connivance with a few private partners during construction and maintenance of several road sector projects in Uganda (New Vision, 2016). As a result, the existing information gaps and the UNRA stakeholders' concerns as to why Uganda is still using contracting out PPP project contract instead of adopting other PPP Project contracts to improve her road sector deserve an in depth investigation (Cheung, Chan \& Kajewski, 2012).

\subsection{Study Objectives}

The main objectives of the study are;

- To examine the relevance of the principal-agency theory to the adoption of PPP project contracts by UNRA

- To establish the types of PPP Project contracts suitable for adoption by UNRA in the roads sector of Uganda. 


\section{Literature Review}

\subsection{Principal Agency Theory and PPP Project Contracts}

The theoretical framework for this study has been derived from the principal-agency theory (Jensen \& Meckling, 1976). In this regard, for effective adoption of PPP Project contracts by UNRA, there is need to understand the nature of the relationship that exists between government and private organisations to work together to deliver services to the citizens through use of principal-agency theory (Holland, 1984). The principal-agent theory emerged in the early 1970s from the integrated aspects of economics and institutional theory. The main quoted reference to the principal-agent theory, however, comes from experts such as William Meckling and Michael Jensen (Barry, 2006). The theory even went beyond institutional and economic studies to different aspects of risk management or uncertainty analysis and information asymmetry.

The occurrence of agency issues has also been broadly evidenced in a number of other scholarly fields such accounting, finance, political science, sociology, organisational behaviour and marketing (Panda \& Leepsa, 2017). The principal-agency theory tries to describe the relationship between two parties, where one is a principal in charge of a certain business and the other is an agent who represents the principal in transactions with a third party (Barry, 2006). Agency relationships exist when the principal employs the agent to do some tasks on his behalf (Bjurstrom, 2020). Whilst the theory has been linked to theorists Stephen Ross and Barry Mitnick, Ross is believed to be the one that initially explained the dilemma of the principal-agency theory in terms of someone choosing a flavour of ice cream for another person despite not knowing that person's preference in terms of taste (Barry, 2006)

The review of principal agency theory focuses on different aspects of the principal agent relationship that have been hypothesized and verified in different study domains (Rose, 2019). Principal agency theory is an analytical lens used for critical assessment of the contractual relations between two parties of a principal and an agent (Addisalem, Henna, Ijaz \& Sari, 2018). The history of the principal agency problem can be traced back to the time when civilisation and development by mankind led to initiation of trade among different people to optimise profits (Panda \& Leepsa, 2017). The principal agency theory as such, rotates around the various aspects of the agency problems and its solutions (Panda \& Leepsa, 2017). Henceforth, the principal agency theory examines the linkage between a number of parties, in which one party known as the principal, obliges another party called an agent, to execute some activities on behalf of the principal (Jussi \& Inga, 2015). Usually the principal seeks to optimise service delivery, while agents focus on maximising economic benefits that accrue from their relationship with the principal (Muhanguzi, 2019). Agency theory contends that an organisation is made up of a nexus of contracts between the owners of economic resources (the principals) and managers (the agents) who are given the responsibility of using such resources to execute certain tasks in order to achieve the intended objectives (Jensen \& Meckling, 1976).

The theory is based on the premise that agents are more informed than principals and that such information disequilibrium results in certain unethical practices which negatively impacts the principals' capacity to effectively monitor and evaluate whether their interests are being well catered for by agents (Holland, 1984). The principal-agent problem may arise if the agent's and principal's interests are parallel and the agent has more knowledge of how to do some work well than what principal knows. In this case, the principal may find it very difficult to make sure that the agent is doing work in the principal's best interest (Jose, Rosa \& Joaquín, 2014). The principal can either enter into a behaviour-based contract or alternatively, an outcome-based contract (Addisalem et. al., 2018). In the first instance, the principal will track the progress of the agent using different avenues such as budgets, reports and board of governors to play an over sight role on the performance of the agent. In the second scenario, the principal can reach a consensus with the agent on certain key result areas. This type of contract helps to clarify well the interests of both the principal and agent (Addisalem et. al., 2018).

There are five important variables, which the principal should consider for choosing the behaviour-based or outcome-based contract with the agent. These include: outcome measurability; outcome uncertainty; task programmability; goal conflict and nature of the agency relationship (Addisalem et. al., 2018). In a long-term relationship, a behaviour-based contract will be more economically viable since in a long-term contract, the principal will have an opportunity to understand better the behaviour of the agent. On the other side, in the short-term contract when the principal may not be able to understand the behaviour of the agent due to limited time scope, an outcome-based contract may be much better to adopt (Addisalem et. al., 2018). Although the principal-agent relationship has got a framework that provides agents with free will conscience so as to operate within certain parameters of any firm, the stakeholders of such firms may possess different interests all together, which make their actions to look as if they were based on self-vested interests (Rose, 2019). This is because the interests of the firm owner are usually totally different from those of the stockholders, each of whom has different interests all together in 
relations to those of the firm's workers. So, the various interests of the different stakeholders of the firm determine the extent to which the good principal agent relationship is enhanced (Rose, 2019).

The principal-agent theory is relevant to the adoption of PPP Project contracts in the roads sector in Uganda because this theory is based on the fact that the success of such PPP project contracts depends on the nature of the relationship between UNRA as a public organisation (principal) and the private partners (agent) that she works with to execute PPP project contracts in the roads sector (McQuaid, 2000). Agency problem is one of the ancient problems that have lingered around since the onset of business organisations. It cannot be ignored since every organisation including UNRA possibly has suffered from the same related problem in different ways (Panda \& Leepsa, 2017). The theory brings to light many aspects of behaviour in the context of adoption of PPP Project contracts by UNRA in the roads sector. UNRA usually signs PPP project contracts with private firms who undertake risky investment projects, and take decisions that UNRA cannot observe or interpret (Sinclair, 2013).

From these contextual assumptions of PPP project contracts and how they can be influenced by the relationships between partners, it is possible to understand how the principal-agency theory applies to this study on the adoption of PPP project contracts in the road sector in Uganda (McQuaid, 2000). Some scholars have however criticised the principal agency theory based on the notion that most academicians who have conducted studies based on principal agency relationships have mainly focussed on the side of the agent's issues and so are of the view that the principal side also has its own issues that need to be dealt with. These scholars have discovered that the principal agency theory is not bothered about the issues associated with principals that always try to take advantage of the agent (Panda \& Leepsa, 2017). In addition, these scholars believe that the agents are made to sign contracts by principals who are just opportunists and in the end the agents may find out that the terms and conditions of the contract only favour the interests of the principals without taking into consideration the interests of the agents, fully. (Panda \& Leepsa, 2017).

\subsection{Types of PPP Project Contracts}

PPP project contracts are collaboration between government and the private sector to provide an effective means of funding infrastructure projects based on good business ethics (Lucely, 2020). A contract is an agreement between two parties that creates mutual legal obligations (LegalMatch, 2020). Contracts are part of everyday dealings in all aspects of life. A contract can either be oral or written. Oral contracts however, are more challenging to enforce and should be avoided, if possible. Some contracts must be written in order to be valid, such as contracts that involve a significant amount of money. It is crucial as such, to understand the rules governing them to ensure acquisition of a valid contract (LegalMatch, 2020). The PPP project contract could be considered an effective pathway for leveraging capital, alleviating uncertainties associated with construction and operation, and achieving a nation's Sustainable Development Goals (Mingyue, Ajith, Basil, Douglas \& Prakash, 2020).

PPP Project contract is an agreement that government makes with the private sector for a period ranging from medium to long term, for provision of services to the citizens. The Government signs such a contract with the private sector specifying precisely how the different associated risks will be shared and also articulately defines the roles and responsibilities of each duty holder (Tshombe \& Molokwane, 2016). According to Solomon et. al., (2014), there are various PPP Project contract types used in the roads sector. The Private Finance Initiative (PFI) PPP project contract was first used by the UK government when it passed a legislation to use it in the construction of a number of highway infrastructure projects (Hu \& Han, 2018). Mehmet and Cuma (2018) contend that a PFI is a type of PPP Project contract where the public entity enters into a contractual arrangement with the private sector entity so that the private entity is authorized to provide services to the public through designing, building, financing and operation of a road facility. The private entity developer is therefore paid by the public entity for the work done to agreed standards in terms of the delivery of services through road facility maintenance (Hu \& Han, 2018). Kamau (2016) insists that nowadays, PPP project contracts to be adopted in constructing and maintaining roads should be hinged on the PPP Project contract of PFI and at the same time on the existing concessions in place (Kamau, 2016).

United States Department of Transportation (2014) postulates that Build Operate and Own (BOO) is a type of PPP Project contract where the public entity enters into contract with a private entity so that the private agency can finance, build, own, and operate a road facility for a certain period of time. The functions of developing, maintaining, and managing the road facility is within the jurisdiction of the private entity. An example is establishment of a logistics and trading centre in China under a BOO contractual arrangement. The Government of Shunyi District and Beijing Municipality signed a contract with Beijing Shunxin Maofeng Logistic Company using a BOO PPP Project contract to construct, operate and manage the trading centre, as the public entity supported the private company to obtain the required land rights (Khadka, 2018). The public entity was free to utilise all the structures and assets of the 
trading centre throughout the Seventh China Expo in 2009. The ADB (2008) asserts that the private entity was motivated to enter into such a contractual arrangement with the public entity because of the advantages that were accrued from using such a BOO PPP project contract which included a one-off award of three to five per cent of private investment in the first year.

A Lease PPP Project contract is where the private sector is responsible for the service in its entirety and undertakes obligations relating to quality and service standards, except for new and replacement investments, which remain the responsibility of the public sector (Obayelu, 2018). Delmon (2010), Farquharson and Yescombe (2011) note that leasing is a type of long term PPP Project contract where a private entity can design, build, refurbish, operate and maintain a service delivered directly to consumers. ADB (2008) agrees that with the leasing PPP project contract, the risk of financing the operation and maintenance of the road facility lies with the private entity, while the public entity retains the risk of financing the initial capital investment for the road facility. Usually leasing is used for a specified period of time which can be between 10 to 20 years and can be renewed for more years depending on performance of the private entity (Bouman, Friperson, Gielen \& Wilms, 2013).

Obayelu (2018) and Vahdatmanesh (2018) argue that Build Operate and Transfer (BOT) is a type of PPP Project contract where the private entity has the sole responsibility for financing, designing, building and operating infrastructure works according to performance standards set by the public sector based on a long period within which the private sector operates the project to pay off costs, make profit and then transfer the asset to the public entity after such a period. Normally, the public entity gives the private entity enough time to operate, maintain and manage the road facility in order to cover all construction costs and other expenses involved (Gwary, Asindaya \& Abba, 2016). Kwak, Chih, \& Ibbs (2009) and Gwary et. al., (2016) affirm that the private entity returns the road facility to the public entity after an agreed period. Although BOT PPP Project contract would bring significant benefits to developing countries like Uganda, it conceals structural vulnerabilities. This has made the private sector hesitant in investing in BOT project contract unless key risks are covered by governments under such PPP project contract arrangements (Tsukada, 2018).

Gwary, Asindaya and Abba (2016), Delmon (2011), Bouman et. al., (2013) believe that management contract or operation and maintenance $(\mathrm{O} \& \mathrm{M})$ is a type of PPP Project contract where a private entity provides some operation and maintenance services for a fee, usually based on delivering satisfactory services. Management PPP contract expands the services to be contracted out to include some or all of the management and operation of a public sector infrastructure service. Although ultimate obligation for service provision remains with the public sector, daily management control and authority is assigned to the private partner or contractor (Obayelu, 2018). Gwary et. al., (2016) assert that such a PPP project contract is a form of operational licence where the public entity agrees with the private agency to be given a license to maintain a certain facility for a particular period of time. In most cases, the public entity pays the private agency an agreed amount of money to cover the overhead costs incurred in maintaining the road facility (Delmon, 2011; Bouman et. al., 2013). However, the public entity is responsible for initial capital investment and delivery of the service to the public and then the private agency is authorised to carry out day to day maintenance and management of the road facility (Bouman et. al., 2013).

United States Department of Transportation (2014) point out that design Build Finance (DBF) is a type of PPP Project contract that involves the private partner providing the necessary capital investment for a new infrastructure facility and is generally repaid by the public sector in a series of instalments funded by taxes, fees or tolls. Adopting the DBF involves providing the required funds to invest in the construction and development of a new road facility so that it can be repaid by the public entity through revenue collected from taxes and toll fees. In most cases, a DBF PPP Project is a short-term financing mechanism ranging between five to seven years after construction of the road facility. The public entity makes payments for such large scale contractual arrangements over a long time in order to make them more affordable (USDOT, 2014).

As already discussed, the Ugandan Government views the use of such PPP project contractual arrangements as an important tool in its plan to bridge the infrastructure financing gap in the next five years (Matti, 2013). Although Uganda is currently using contracting out PPP project contracts to construct and rehabilitate some roads in different parts of the country such as Mukono Katosi road, it is planning to adopt the use of other PPP project contracts such as management contract for the Kampala-Entebbe expressway and the Build-Operate-Transfer (BOT) PPP Project contract for Kampala-Jinja high way to implement more road construction and maintenance projects (Tony, 2013). 


\section{Methodology}

This study, adopted a qualitative approach under a case study research strategy (Baxter, 2008; Yin, 2009; Creswell, 2013). The study population consisted 15 key stakeholders of UNRA. Hence a sample size of 15 respondents was targeted (Creswell, 2014). This is because some research experts recommend that the number of participants for a qualitative study should be between 5 to 50 people (Shari, 2012). Purposive sampling was used to identify and select respondents. Selected participants from UNRA were those who were involved either directly or indirectly in the adoption of PPP contracts. These included 5 members of the PPP unit, 4 senior managers of UNRA and 6 staff from UNRA regional offices. The purposive sampling was chosen out of the need to understand the perceptions of UNRA stakeholders on the key issues pertaining to PPP contracts in the roads sector. Purposive sampling was used to select participants who were experts in the area of PPP project contracts in the roads sector from the PPP unit (Saunders et. al., 1997; Yazan, 2015).

These respondents were purposively selected due to: the background knowledge; skills; responsibility; stake they had in the different PPP contracts being used to implement various projects in the roads sector in Uganda; their willingness to participate in the study; their ability to address the research questions and fully describe the phenomenon being studied. All these factors were very critical to making decisions for final selection of respondents for interviews (Ritchie \& Lewis, 2003). For these reasons, each UNRA stakeholder was purposely identified and interviewed. Primary data was collected using interview guides. While secondary data was obtained using literature review (Joubish, Kharram, Ahmed, Fatima \& Haider, 2011). Face-to-face in-depth interviews were conducted using unstructured interview guides that had open-ended questions with a view to yield adequate narrative data that could best inform the study. In this case the interviewer had opportunity of freedom to ask for additional, non-planned questions according to the responses of the participants (Hashemnezhad, 2015). It was ensured that the interviews conducted were systematic, credible, and transparent which enabled the study participants to reproduce the obtained expected results (Patton \& Cochran, 2002). The respondents were contacted first by email and then by phone calls. People from different regions, departments and offices of UNRA were contacted and interviewed. Interviews were tape-recorded where necessary and whenever it was possible.

Notes were also taken simultaneously alongside tape recording allowing verification of what had been said, and to complete notes afterwards (Sobuza, 2010). Most questions focused on some key constructs related to PPP Project contracts. Questions were formulated from the emerging issues identified from quantitative analysis for in-depth analysis of the phenomenon under the study (Stake, 2010). Data was analysed by use of narrations and descriptions (Braun \& Clarke, 2006). Statements by UNRA experts were logically presented in narrative form. Other statements considered of high importance were also mentioned in the text and results were then interpreted and discussed in line with the reviewed literature (Schutt, 2011). After data recording and storage, data was edited for completeness, accuracy, and comprehensibility before final data analysis (Braun \& Clarke, 2006). Qualitative data was transcribed, sorted, edited, classified and coded into suitable categories. Data was then condensed into memos to ease coding and later analysed (Creswell, 2013). Some data that was not useful was discarded. Themes were then formulated with code categories assigned either a letter code or a figure code to each category (Braun \& Clarke, 2006). Data analysis began immediately after coding. Analysis of data was guided by the research objectives (David, 2006) which identified PPP Project contracts that had been investigated. Efforts were made to follow any new leads or perspectives, which were not anticipated during interviews with different respondents. Probing into more detailed aspects of the research, which were deemed necessary was also done.

This led to the interpretive phase, which was the heart of qualitative data analysis (Creswell, 2007). Information was interpreted with its corresponding results by assigning meaning to the figures, observations, opinions and perceptions of the UNRA stakeholders (Lofland, 1971). Qualitative data was interpreted by composing explanations or descriptions from the information coded and arranged (Ritchie \& Lewis, 2003). Finally, qualitative data such as stories, answers to open questions or observation of behaviour with a good understanding of the situation was analysed, but also with an open mind to minimise professional and personal bias. After all the above were done, key words or issues were looked out for in order to structure and organise the information for comparison. Answers were then clustered around such key words or issues and looked for patterns and any relationships before disseminating findings (Ritchie, Lewis \& Elam, 2003; Ritchie \& Lewis, 2003). After qualitative data was analysed, findings were presented as direct quotations from the participants. The research objectives of this study formed the major headings where quantitative finding were presented. The research objectives were used to guide the presentation of the findings in a clearer and understandable manner because they sought to answer the research problem of the study (De Vos, 2005). In doing all these, the researchers made sure that it was important for them to keep in mind that generalizations had to be made carefully in a qualitative study, because of the bias that could have emerged from 
interviews they held with the different UNRA respondents. Finally, the qualitative results were used to make certain conclusions and recommendations on the adoption of PPP Project contracts in the roads sector in Uganda.

\section{Results}

\subsection{Results From Literature Review on Relevance of the Principal-Agency Theory}

A review of literature substantiated this study's findings indicating that the principal-agency theory is relevant and can be used to explicate the adoption of PPP project contracts by UNRA. It was determined that UNRA is the principal representing the public sector and any private company that UNRA intends to partner with in executing PPP project contracts in the roads sector is the agent. If UNRA as principal is to adopt the use of PPP Project contracts in the roads sector, she needs to get a private partner as an agent that has the capacity to execute the road works which herself as the principal cannot be able to do (Müller \& Turner, 2005). That is why during the process of selecting the agent, UNRA as a principal needs to be very critical by strictly following the right PPP Project contacting process thus exercising caution on any transaction (Saam, 2007; Poulton \& Macartney, 2012).

Awarding a PPP project contract by UNRA to a wrong private agent raises a likelihood of emergence of a dispute between the partners hence one party is likely to be more favoured than the other, leading to arms-length contractual relations. In most cases, the principal and agent are not equally positioned well, and so UNRA as the principal needs to learn to work well with private partners who are its agents in the execution of PPP Project contacts. In addition, the management of the PPP project contract needs to be a concerted effort of different stakeholders of the principal such as user departments and the public procurement and disposal unit to minimise the uncertainties associated with PPP Project contract implementation by both the principal and his agent (Poulton \& Macartney, 2012). The theory prescribes that much as a PPP project contract administration needs to be done by the user departments of the principals that are directly affected by the implementation of such contract, in order to effectively detect any performance deviation early enough, the principal's PPP project contact manager needs to always work closely with the agent's PPP project contactor.

It is, therefore, obligatory to come up with a well-developed plan as a basis for effective contract management by involving different stakeholders of both the principal and agent, and assigning roles and responsibilities to each of the parties involved (Babayan \& Kadlecikova, 2016; Roach, 2016). This study has chosen to apply the principal-agent theory to critically assess the possible outcomes of the agency relationship that result from the interaction between the principal and agent and the likely implications to the PPP Project contacts in the roads sector in Uganda. The theory can, therefore, be used by UNRA to explore the challenges of agency problems in contractual arrangements it intends to have with private entities in the execution of the different PPP project contracts in the roads sector. Since the principal agent theory is a model where the principal delegates tasks to the agent (Babayan \& Kadlečíková, 2016:315; Roach, 2016), Hlavaeek \& Hlavaeek (2006) look at it as if the principal is striking a balance with an agent in terms of effective contract management and administration. This culminates into an agency relationship where an agent acts for, or as a representative of, the principal (Babayan \& Kadlecikova, 2016:316; Shankman, 1999:321; Turner, 2004; Muller \& Turner, 2005).

\subsection{Results From Types of PPP Project Contracts to Be Adopted by UNRA in the Roads Sector}

\subsubsection{Findings for Adoption of Private Finance Initiative (PFI) PPP Project Contract}

During interviews with respondents concerning the use of Private Finance Initiative type of PPP Project contract in the roads sector, the majority of respondents said that they did not know because they had never heard about such terms. However, one respondent said: "I believe if UNRA goes ahead to use Private Finance Initiative types of PPP Project contracts in the roads sector, it may not be good for our country because the private companies may over exploit the public." Another respondent said: "I think it may be a good idea for UNRA to use Private Finance Initiative PPP Project contract because if it works with private companies, for them they are more serious". Another one respondent said: "If not mistaken, I am not quite sure whether we intend to use a Private Finance Initiative type of PPP Project contracts here in UNRA. May be I need to first do my homework before I confirm." The above qualitative finding indicates that UNRA may not be intending to use Private Finance Initiative type of PPP Project contract. So the finding is not in line with what the researcher intended to measure. Over all, results from interview show that UNRA is currently not planning to use such type of PPP Project contract in the roads sector and as already noted, the results are not all in line with what the researcher intended to measure.

\subsubsection{Findings for Adoption of Design-Build (DB) PPP Project Contract}

Concerning UNRA's intention to use of DB PPP Project contract in the roads sector, the majority of respondents said that they were not aware of such PPP project contractual arrangement in UNRA. Respondent 1 said: "I doubt there is 
such PPP Project contract in this organization but if UNRA has a plan to introduce it, it is okay." Respondent 2 said: "I don't know whether we are intending to use such PPP Project contract but even if UNRA is planning to have such PPP project contract in place, personally I won't support it because it attracts more Chinese firms to grab people's land and put up fake roads." On the other hand, Respondent 3 said: "I am not aware of the existence of such type of PPP Project contract in UNRA but if UNRA intends to use such PPP project contract in the near future, that will be good." Respondent 4 said: "I am not quite sure that we have such a PPP Project contract here and so I can't say much" while Respondent 5 said: "For sure I can't deceive that I have ever heard about something like that. "All the above support the findings from quantitative data that showed that UNRA is currently not using these PPP Project contracts of Design-Build. The findings are not in line with what was intended to be measured.

\subsubsection{Findings for Adoption of Leasing PPP Project Contract}

Interviews with respondents concerning UNRA's intention to use Leasing PPP Project contract in the roads sector revealed that the majority of respondents said that 'they don't know whether such PPP project contract can be used in constructing roads in Uganda'. Some of the respondents said that "if such idea ever came up, they would support it especially when it comes to acquisition of land for roads construction." Actually one of the respondents said: "I am not aware of such PPP Project contract in UNRA but if it was to be adopted, it would be a good opportunity especially when it comes to accessing land for constructing more roads especially in urban areas. While another respondent said: "Well, I have not yet heard about it but if it ever comes up, I don't think I would support such an idea because many people here in Uganda are thieves." All the above qualitative findings indicate that UNRA is not intending to use Leasing PPP Project contract in the roads sector and so the results are not in line with what the researcher intended to measure.

\subsubsection{Findings for Adoption of UNRA's Intention to Use BOT PPP Project Contract}

On interview with respondents concerning UNRA's intention to use Build Operate Transfer PPP Project contract in the roads sector, a number of respondents said that currently this PPP Project contract is not operational but it's being designed for some roads such as Kampala Jinja express highway. One of the responds asked: "So, how did you know we already have a plan in place to use such PPP Project contract?" Respondent 2 said: "Of course the plan is already there and I don't think there is anyone who does not support that plan because it is going to enable us work with private companies that can provide us with better expertise and more resources that we may not be having at hand currently." Respondent 3 said: "I reserve my comments because a number of other good plans have always been in place but they never materialize." All the above qualitative findings support UNRA's intention to use Build Operate Transfer (BOT) PPP Project contract in the roads sector and is in line with what the researcher intended to measure. The results indicate that UNRA has a plan already in place to use the above PPP Project contract in the roads sector in Uganda before the end of 2021. All the above results agree with what the researcher intended to measure.

\subsubsection{Findings for Adoption of Management Contract PPP Project Contract}

Interviews with respondents on whether UNRA is currently intending to use management PPP Project contract in the roads sector, showed that the majority of the respondents agreed that "UNRA is intending to use management contract to construct more roads in Uganda." One of the respondents said: "It is true UNRA is trying to get a private firm to take over management of the Kampala-Entebbe express highway so that it can charge toll fees from the motorists." Another respondent noted: "We are currently intending to use management contract with some private partners to provide us certain critical services we need in road construction and maintenance". While, another observed: "I think it may not be a good idea to have a management contract with some private firms to provide us certain critical services we need in road construction and maintenance because some of the private partners may be compromised by the wrong characters in UNRA." All the above support the findings from qualitative data on the intention to use, management PPP Project contract by UNRA in the roads sector in Uganda and they agree with what the researcher intended to measure. Over all, results show that UNRA is currently intending to use mainly management PPP Project contracts in the roads sector in Uganda.

\subsubsection{Findings for Adoption of Design, Build and Finance (DBF) PPP Project Contract}

During interviews with respondents concerning UNRA's intention to use Design, Build and Finance (DBF) PPP Project contract in the roads sector in Uganda, many of the respondents commented that they "had never heard about such PPP Project contract in the circles of UNRA." Actually one respondent lamented: "I am afraid that is just here say. Who told you we have plans to use such PPP Project contract here?" Respondent 2 asked: "Are you sure of what you are talking about? Better check your notes properly." On the other hand, Respondent 3 observed: 'I wish 
we had such a plan in place at present because many international companies like those from china would be willing to invest in construction of underground tunnels to modernize our city transport in Kampala as long as UNRA is ready to support such firms to do so." Respondent 4, however, noted that "a lot of dialogue with different stakeholders is required before such PPP Project contract can be introduced since it may even call for parliament's approval." Respondent 5 commented: "Even if we had plans for that PPP Project contract, such plans are not easy to implement in the short term due to heavy expenses involved." While Respondent 6 said: "I am afraid you are in a wrong place if you are talking about such a PPP Project contract." All the above qualitative findings indicate that UNRA has not yet and does not have intentions to adopt Design, Build and Finance (DBF) PPP Project contract in the roads sector in Uganda and so the results are not in line with what the researcher intended to measure.

\section{Discussion}

\subsection{The Relevance of the Principal-Agency Theory to the Adoption of PPP Project Contracts}

Findings from review of literature revealed that as the principal, UNRA selects private parties (agents) that have ability to perform their roles and responsibilities well to undertake the tasks that the principal may not be in position to do so. This may be especially true when it comes to accessing certain critical information pertaining to contract management and as a result, the principal may fail to understand the reasons behind making certain choices, decisions and actions by the agents, and whether the right actions are being made on their behalf.

This finding is line with what scholars such as Jensen \& Meckling (1976) who contend that, for effective adoption of PPP Project contracts in the roads sector, there is need to understand the nature of the relationship that exists between government and private organisations to work together to deliver services. Secondly, this theory agrees with Holland (1984) who says that for effective PPP Project contract management, there is need for the principal to work well with the agent to execute such PPP contacts. Thirdly, this finding supports the works of scholars such as Barry (2006) who opines that the success of such PPP project contracts in the roads sector depends on the nature of the relationship between public partners (principal) and private partners (agent). Also this finding is in line with McQuaid (2000) who observes that the principal-agency theory tries to describe the relationship between two parties, where one is a principal in charge of a certain business and the other is an agent who represents the principal in transactions with a third party.

In addition, this finding agrees with scholars such as Bjurstrom (2020), Panda and Leepsa (2017) who assert that agency relationships exist when the principal employs the agent to do some tasks on his behalf. So the theory as such, rotates around the various aspects of the agency problems. It cannot be ignored since every organisation has suffered from such problem. More to that, this finding supports the work of Rose, (2019) who conjures that the review of principal agency theory focuses on different aspects of the principal agent relationship that have been hypothesized and verified in different study domains. Last but not least, this finding concurs with researchers such as Addisalem, Henna, Ijaz and Sari (2018) who opine that principal agency theory is an analytical lens used for critical assessment of the contractual relations between two parties of a principal and an agent. Finally, this finding is in agreement with researchers such as Muhanguzi (2019) who believes that usually the principal seeks to optimise service delivery, while agents focus on maximising economic benefits that accrue from their relationship with the principal.

\subsection{Types of PPP Project Contracts to Be Adopted by UNRA in the Roads Sector}

In terms of types of PPP project contacts to be adopted UNRA in the roads sector in Uganda, the findings revealed that a number of respondents interviewed disagreed with the statement that UNRA intends to adopt Public Finance Initiative PPP Project contact in the roads sector. Therefore, this finding of the study does not reflect the reviews of scholars such as Mehmet \& Cuma (2018), Hu \& Han (2018) and Kamau (2016) who contend that a Public Finance Initiative (PFI) is a type of PPP project contract where the public entity enters into a contractual arrangement with the private sector entity so that the private entity is authorized to provide services to the public through designing, building, financing and operation of a road facility.

In addition, it was revealed that majority of respondents interviewed disagreed with the statement that UNRA intends to adopt Design Build (DB) PPP project contract in the roads sector. Therefore, this finding of the study does not agree with the debates by scholars such as Khadka (2018) and Gwary et. al., (2016) who assert that Design Build is a type of PPP project contract, where the private entity designs and builds a facility in line with the needs of the public entity for a specific amount of money. It was also discovered that all the respondents interviewed disagreed with the statement that UNRA intends to adopt leasing PPP project contract in the roads sector. Therefore, this finding does not reflect the reviewed debates by scholars such as Obayelu (2018), Delmon (2010), Farquharson and Yescombe 
(2011) who note that leasing is a longer term type of PPP project contract where a private entity can design, build, refurbish, operate and maintain a service delivered directly to consumers.

Thirdly the findings revealed that majority of the respondents interviewed agreed with the statement that UNRA intends to adopt Build Operate-Transfer (BOT) type of PPP project contract in the roads sector in Uganda. This finding of the study is in line with scholarly debates by Obayelu (2018) and Vahdatmanesh (2018) who argue that BOT is a type of PPP project contract where the private entity has the sole responsibility for financing, designing, building and operating infrastructure works according to performance standards set by the public sector based on a long period within which the private sector operates the project to pay off costs, make profit and then transfer the asset to the public entity after such a period.

In addition, it was revealed that a number of respondents interviewed agreed with the statement that UNRA intends to adopt Management contract type of PPP project contract in the roads sector. This finding reflects the reviewed debates by scholars such as Gwary et. al., (2016), Delmon (2011) and Bouman et. al., (2013) who believe that management contract or operation and maintenance $(\mathrm{O} \& \mathrm{M})$ is a PPP project contract arrangement where a private entity provides some operation and maintenance services for a fee, usually based on delivering satisfactory services. Finally, it was also discovered that many of the respondent interviewed disagreed with the statement that UNRA intends to adopt Design Build Finance PPP project contract in the roads sector in Uganda. This finding does not agree with the views of development agencies such as United States Department of Transportation (2014) who point out that DBF is a type of PPP project contract where the private partner provides the necessary capital investment for a new infrastructure facility and is generally repaid by the public sector in a series of instalments funded by taxes, fees or tolls, which is not the case with UNRA.

\section{Recommendations}

\subsection{The Relevance of the Principal-Agency Theory to the Adoption of PPP Project Contracts}

From the review of literature, it was found that the principal-agency theory is relevant to the adoption of PPP project contracts by UNRA. Based on this finding, UNRA as a principal, needs to base its relationship with the private partners as agents on the objectives of the principal- agency theory. In this regards, UNRA needs to be very critical when selecting a private agency to contract when implementing PPP projects. So UNRA has to do so by strictly following the right PPP Project contacting process so as to avoid any possible hidden intentions and actions of the agent to be awarded the PPP project contact that may not be easily identified by the principal, and yet, they are very crucial in determining how much compensation can be given to the agent. Further to this, UNRA needs to learn to work well with private agencies in the execution of PPP Project contacts if it is to realise quantum results as far as effective, efficient and economic gains in the roads sector are concerned. Additionally, UNRA needs to always conduct a thorough needs assessment and bid evaluation to get the best evaluated contractor and dual diligence before awarding a PPP project contact to any private agency. The management of the PPP contract needs to make a concerted effort to involve different UNRA stakeholders when adopting PPP project contract, to minimise the uncertainties associated with PPP project contract implementation by both the principal and his agent.

\subsection{Types of PPP Project Contracts to Be Adopted by UNRA in the Roads Sector}

Majority of the UNRA stakeholders were of the view that UNRA intends to use management contract PPP project contacts. Based on this finding, UNRA should not only adopt the use management PPP project contract but also should endeavour to use other PPP project contracts such as Public Finance Initiative, Leasing, Design Build and Design Build and Finance. Secondly any type of PPP Project contract to be adopted by UNRA should always present enough opportunities for generation of new ideas for better management of contracts when working with its private sector partners to implement different PPP projects in the roads sector in Uganda. Thirdly any type of PPP Project contract to be adopted by UNRA should be one that leads to substantial reduction in construction time for national roads when working with its private sector partners to implement different PPP projects in the roads sector in Uganda.

If implemented well, any type of PPP Project contract to be adopted by UNRA in the roads sector should lead to improved efficiency in terms of reducing wastage and using minimum inputs to maximize out puts, in construction of national roads. In addition, any type of PPP Project contract to be adopted by UNRA should always lead to improvements in the quality of service as well as effectiveness in terms of ensuring that whatever is being done is in line with achieving the set PPP project objectives. Finally, any type of PPP Project contract to be adopted by UNRA should enable both the public partner and private partners to reduce costs and achieve substantial savings. 


\section{Conclusion}

The principal-agency theory remains relevant to the adoption of PPP project contracts in Uganda. As indicated in the study, UNRA as the government organisation is the principal and while the private partners that work with her in the use of PPP project contracts to construct and maintain roads in Uganda are agents. In such a scenario, Public sector organisations such as UNRA normally identify, evaluate and sign contracts with private contractors as agents as long they have the knowledge, skills, experience and resources to do some assignment that the principal cannot do himself especially when it comes to accessing certain critical information pertaining to PPP Project contract management. Various types of PPP project contracts can be adopted by UNRA in the roads sector. A number of factors come into play here. From the review of literature and a number of documents in addition to the interviews conducted with different stakeholders of UNRA, the study revealed that although UNRA intends to use some PPP Project contract, currently she does not intend to use other PPP project contracts. Secondly UNRA is currently using mainly the PPP project contracts of contracting out and management contracts in the roads sector in Uganda. Thirdly there is a very low probability that UNRA is planning to use leasing PPP project contract in the roads sector in Uganda. There is as well, a very low likelihood that UNRA is planning to use Build, Own (BO) PPP project contract in the roads sector in Uganda. In addition, there is a very high chance that UNRA is planning to adopt the Build, Own and Transfer (BOT) PPP project contracts in the roads sector in Uganda. Finally, it has also been observed that there is a very minimal opportunity that UNRA may be planning to adopt the use of Design Build (DB) PPP project contract in the roads sector in Uganda.

\section{References}

Addisalem, T. Y., Henna, J., Ijaz, A., \& Sari, T. (2018). Exploring principal-agent theory in higher education research.

African Development Fund. (2010). Project Appraisal Report of Capacity Building for PPP Infrastructure (Cb4pppi) in Nigeria.

Alan, R. (2010). PPPs in Highway Construction: Arizona State University.

Andrew, B. (2013). The Public Private Partnership model in the UK, PFI in the UK and PPP in Europe. Retrieved from http://www.thecityuk.com/research/our-work/reports-list

Asian Development Bank. (2015). Report on evaluating the environment for public private, Partnerships in Asia-Pacific. The Economist Intelligence Unit.

Babayan, D., \& Kadlečíková, M. (2016). Principal-agent model in agricultural based projects in the Republic of Armenia. https://doi.org/10.15414/isd2016.s5.01

Barry, M. M. (2006). Origin of the Theory of Agency: An Account by of the principal agency theory. Katz Graduate School of Business, University of Pittsburgh.

Baxter, P., \& Jack, S. (2008). Qualitative Case Study Methodology: Study Design and Implementation for Novice researchers. The Qualitative Report, 13(4), 544-559.

Bjurstrom, K. H. (2020). Principal-Agent or Principal-Steward: How principals relate with agents in organisations. Retrieved May 24, 2020, from www.tandfonline.com>full>15309576.2020.1739087

Bouman, S., Friperson, R., Gielen, M., \& Wilms, P. (2013). Public-Private Partnerships in developing countries. IOB Evaluations (Netherlands) eng no. 378.

Braun, V., \& Clarke, V. (2006). Using thematic analysis in psychology. Qualitative Research in Psychology, 2(2), 4. https://doi.org/10.1191/1478088706qp063oa

Buehring, S. (2019). What is a project?. Definition of a project according to prince 2.

Cesar, Q., \& Carlos, E. M. (2012). A Review of Critical Steps for Implementing Public-Private Partnerships in Brazil.

Charles, L., Hugh, M., \& Joseph, B. (2013). PPPs to Improve Transport Infrastructure in Canada.

Cheung, E., Chan, A. P. C., \& Kajewski, S. (2012). Reasons for Implementing Public Private Partnership projects in schools. Perspectives from Hong Kong and Australian.

Coopers, P. W. (2009). Public Private Partnerships. A United States of America Perspective.

Creswell, J. W. (2013). Qualitative Inquiry and Research Approaches: Choosing among Five, Traditions Thousand Oaks, $C A$ (2nd ed.). Thousand Oaks. California: Sage. 
Creswell, J. W. (2014). Research Design: Qualitative, Quantitative \& Mixed Methods Approaches, International Etudent Edition, CA (4th ed.). Thousand Oaks, California: Sage.

Creswell, W. J. (2007). Qualitative Inquiry and Research Design: Choosing Among Five Approaches. London: Sage Publications.

David, R. T. (2006). A General Inductive Approach for Analysing Qualitative Evaluation Data. Sage Publications Ltd.

De Vos, A. S. (2005). Scientific theory and professional research; Building a scientific base for the helping professions.

Delmon, J. (2010). Understanding Options for Public-Private Partnerships in Infrastructure. Sorting out the forest from the trees: BOT, DBFO, DCMF, concession, lease 75. Policy Research Working Papers. https://doi.org/10.1017/CBO9780511974403

Delmon, J. (2011). Public-private partnership projects in infrastructure: an essential guide for policy makers. Cambridge University Press.

Dworkin, S. L. (2012). Sample Size Policy for Qualitative Studies Using In-Depth Interviews. Archives of Sexual Behavior, 41, 1319-1320. https://doi.org/10.1007/s10508-012-0016-6

Farquharson, E., \& Yescombe, E. (2011). How to engage with the private sector in public-private partnerships in emerging markets. World Bank Publications. https://doi.org/10.1596/978-0-8213-7863-2

Gwary, M. M., Asindaya, Z., \& Abba, M. A. (2016). Public-private partnership as panacea for effective extension service delivery. Review of experience and potential in Nigeria.

Hans, G. (2016). The Role of Institutional Investors in Financing Development in Asia and the Pacific. Macroeconomic Policy and Financing for Development Division.

Hashemnezhad, H. (2015). Qualitative Content Analysis Research: A Review Article. Journal of ELT and Applied Linguistics (JELTAL), 3(1).

Hlavaeek, J., \& Hlavaeek, M. (2006). "Principal-Agent" Problem in the Context of the Economic Survival. Acta Oeconomica Pragensia, 2006(3), 18-33. https://doi.org/10.18267/j.aop.81

Holland, R. C. (1984). The New Era in Public-Private Partnerships. In P. R. Porter, \& D. C. International Road Federation (IRF) (Eds.), Public-Private Partnerships Executive Seminar: Better Roads for Better World.

Hu, X., \& Han, J. (2018). Highway Project Value of Money Assessment under PPP Mode and Its Application. https://doi.org/10.1155/2018/1802671

Jamali, D. (2004). Success and failures mechanisms of PPPs in Developing countries: insights from the Lebanese context. The International Journal of Public Sector Management, 17(5).

Jensen, M. C., \& Meckling, W. H. (1976). Theory of the firm: Managerial behaviour, agency costs and ownership structure.

Jose, A. G., Rosa, R. S., \& Joaquín, F. V. (2014). The Principal-Agent Problem in Peer Review. Journal of the Association for Information Science and Technology, 66(2).

Joubish, M. F., Kharram, M. A., Ahmed, A., Fatima, S. T., \& Haider, K. (2011). Paradigms and Characteristics of a Good Qualitative Research. World Applied Sciences Journal, 12(11), 2082-2087.

Jussi, K., \& Zalyevska, I. (2015). Agency Theory as a Framework for Higher Education Governance.

Kamau, S. (2018). Kenya will benefit from Public Private Partnerships in mega Projects.

Khadka, R. (2018). Management Control in Public Private Partnership: A Comparative Case Study of Norwegian and Australian Road Projects.

Kwak, Y. H., Chih, Y., \& Ibbs, C. W. (2009). Towards a comprehensive understanding of public private partnerships for infrastructure development. California Management Review, 51(2), 51-78. https://doi.org/10.2307/41166480

Lofland, J. (1971). Analysing qualitative research data in a Social Settings. Belmont, CA: Sage.

Lucely, V. P. (2020). Sustainable Public-Private Partnership (PPP) Projects in Colombia. Part of the CSR, Sustainability, Ethics \& Governance book series. 
Match, L. (2020). What is a Contract? LegalMatch Law Library Managing Editor and Attorney at Law. Retrieved from https://www.legalmatch.com/law-library/article/what-is-a-contract.html

Matti, S. (2013). Is there a Distinctive Canadian PPP Model? Reflections on 20 Years of Practice.

McQuaid, R. W. (2000). The Theory of Partnerships - Why Have Partnerships. In S. P. Osborne, \& R. W. McQuaid (Eds.), Local Enterprise Companies and Rural Dev't, Journal of Rural Studies.

Mehmet, T., \& Cuma, S. (2018). Opinions and evaluations of stakeholders in the implementation of the public - private partnership (PPP) model in integrated health campuses (city hospitals) in Turkey.

Mingyue, S., Ajith, V. S., Basil, S., Douglas, W., \& Prakash, R. (2020). Economic analysis of dynamic inductive power transfer roadway charging system under public-private partnership-Evidence from New Zealand. https://doi.org/10.1016/j.techfore.2020.119958

Muhanguzi, K. B. (2019). An Empirical Test of the Agency Theory in Corporate Governance of SACCOs in Uganda. Kampala International University and Makerere University. https://doi.org/10.2139/ssrn.3454396

Muller, R., \& Turner, J. R. (2005). The impact of principal-agent relationship and contract type on communication between project owner and manager. International Journal of Project Management, 23(5), 398. https://doi.org/10.1016/j.ijproman.2005.03.001

Mulyungi, P. (2019). Uganda begins demarcating Standard Gauge Railway (SGR) line route.

Obayelu, A. E. (2018). Public-Private Partnerships for Inclusive. Agribusiness Sustainability in Africa.

Panda, B., \& Leepsa, N. (2017). Agency theory: Review of Theory and Evidence on Problems and Perspective. Indian Journal of Corporate Governance, 10(1), 74-95. https://doi.org/10.1177/0974686217701467

Patton, M., \& Cocharn, M. (2002). A Guide to Using Qualitative Research Methodology. Médecins Sans Frontières, Paris. H.

Poulton, C., \& Macartney, J. (2012). Can public private partnerships leverage private investment in agricultural value chains in Africa? A preliminary review. World Development, 40(1), 96. https://doi.org/10.1016/j.worlddev.2011.05.017

Ritchie, J., \& Lewis, J. (2003). Research patterns and relationships when disseminating study results.

Ritchie, J., Lewis, J., \& Elam, G. (2003). Qualitative research practice: A guide for social science students and researchers. Designing and Selecting Samples, 2, 111-145.

Roach, C. M. (2016). An Application of Principal Agent Theory to Contractual Hiring Arrangements within Public Sector Organizations. Theoretical Economics Letters, 6(1), 28. https://doi.org/10.4236/tel.2016.61004

Rose, M. B. (2019). The Agency of the Principal-Agent Relationship: An Opportunity for Human resource development.

Saam, N. J. (2007). Asymmetry in information versus asymmetry in power: Implicit assumptions of agency theory?. The Journal of Socio-Economics, 36(6), 825-840. https://doi.org/10.1016/j.socec.2007.01.018

Schutt, R. K. (2011). Qualitative Data Analysis. Investigating the Social World: The Process and Practice of Research (7th ed.). Sage Publications.

Shankman, N. A. (1999). Reframing the debate between agency and stakeholder theories of the firm. Journal of Business Ethics, 19(4), 319-334. https://doi.org/10.1023/A:1005880031427

Sinclair, P. (2013). Principal-Agent Theory; Why Bonuses may be Beneficial. Handbook of Safeguarding Global Financial Stability.

Sobuza, Y. (2010). Social housing in South Africa: Are Private-Public Partnerships (PPPs) a solution.

Solomon, O. B., Srinath, P., Chika, U., \& Lei, Z. (2014). Challenges of Implementing Infrastructure Megaprojects through Public-Private Partnerships in Nigeria: A Case Study of Road Infrastructure. International Journal of Architecture, Engineering and Construction.

Stake, R. E. (1995). The art of case study in research methodology for academic researchers. Sage.

Tony, B. K. (2013). Uganda Transport Infrastructure and the Public-Private partnerships. 
Tshombe, L. M., \& Molokwane, T. (2016). An analysis of public private partnership in emerging economies. Risk Governance \& Control: Financial Markets \& Institutions, 6(4), 306-316. https://doi.org/10.22495/rgcv6i4c2art8

Tsukada, S. (2018). Vulnerabilities of BOT Scheme and Ways to Overcome Them Under PPP: Cross-Country Comparison of PPP Systems Among Selected Countries. https://doi.org/10.1177/1087724X18799762

Turner, J. R. (2004). Farsighted project contract management: incomplete in its entirety. Construction Management and Economics, 22(1), 75-83. https://doi.org/10.1080/0144619042000186077

United States Department of Transportation (USDOT). (2014). Types of Public-Private Partnerships (P3s). United States.

Vahdatmanesh, M. (2018). Price risk management in BOT railroad construction projects using financial derivatives. Journal of Financial Management of Property and Construction. https://doi.org/10.1108/JFMPC-04-2018-0021

Vision, N. (2016). Reported cases of alleged corruption among UNRA officials and its private partners. Ugandan government's official News Paper, 30, 5-27.

Yin, R. K. (2009). Case Study Research: Design and Methods (4th ed., Vol. 5). Singapore. Washington D.C: Sage Publications Ltd.

\section{Copyrights}

Copyright for this article is retained by the author(s), with first publication rights granted to the journal.

This is an open-access article distributed under the terms and conditions of the Creative Commons Attribution license (http://creativecommons.org/licenses/by/4.0/). 